\title{
A CONFISSÃO DE LÚCIO: NARCISO, O ESPELHO E A MORTE
}

\author{
Teresa Cerdeira*
}

Je dis qu'il faut être voyant, se faire voyant.

Le Poète se fait voyant par un long, immense et raisonné dérèglement de tous les sens. Toutes les formes d'amour, de souffrance, de folie; il cherche lui-même, il épuise en lui tous les poisons, pour n'en garder que les quintessences. Ineffable torture où il a besoin de toute la foi, de toute la force surhumaine, où il devient entre tous le grand malade, le grand criminel, le grand maudit, - et le suprême Savant - Car il arrive à l'inconnu! Puisqu'il a cultivé son âme, déjà riche, plus qu’aucun! Il arrive à l'inconnu, et quand, affolé, il finirait par perdre l'intelligence de ses visions, il les a vues!

Arthur Rimbaud

Começo por agradecer a honra do convite que me foi feito para participar desta mesa de encerramento da jornada em homenagem a Mário de Sá-Carneiro, que bem pode ser entendida como uma avant première dos justos festejos pelos 100 anos da Modernidade de Orpheu a se comemorarem no próximo ano de 2015. A ideia inicial era a de eu reiterar aqui algumas das consideraçôes que já fizera anteriormente sobre $A$ Confissáo de Lúcio e que acabam de ser publicadas na coletânea $A$ Mão que escreve. Julguei contudo que, passado o tempo sobre as primeiras conclusóes que eu elaborara sobre essa novela de Sá-Carneiro, algumas outras questôes se tinham vindo a interpor que talvez merecessem o privilégio de uma atenção.

\footnotetext{
* Professora Titular de Literatura Portuguesa da Universidade Federal do Rio de Janeiro e pesquisadora do CNPq.

${ }^{1}$ Digo que é preciso ser vidente, tornar-se vidente. O Poeta se torna vidente por um longo, imenso e refletido desregramento de todos os sentidos. Todas as formas de amor, de sofrimento, de loucura; ele próprio busca, esgota em si mesmo todos os venenos, para só guardar deles a quintessência. Inefável tortura em que ele precisa de toda a fé, de toda a força sobre-humana, em que ele se torna entre todos o grande doente, o grande criminoso, o grande maldito - e o Sábio supremo! - Porque ele chega ao desconhecido! Já que cultivou a sua alma, já rica, mais que qualquer outro! Ele chega ao desconhecido; e quando, enlouquecido, acabar perdendo a inteligência de suas visōes, ele as terá visto! (tradução minha)
} 
A base da leitura a que me referi - A Confissáo de Lúcio, um ensaio sobre a voluptuosidade - fora fundada na hipótese de que esta novela, em que coabitam gêneros poéticos distintos tais como a poesia, a narrativa fantástica, a narrativa policial, a narrativa autobiográfica, se poderia ver acrescida ainda de uma estrutura ensaística - a referir aqui o rigor demonstrativo do enredo exemplar - o que, em outras palavras, permitiria ler a obra como um ensaio sobre a voluptuosidade que se desdobrasse em três tempos: a teorização, a encenação e a experimentação.

\section{Da teorizaçáo:}

No que tange aos personagens da novela, composta de não mais de cinco actantes masculinos de maior ou menor importância em termos consequentes para a trama, uma figura feminina, na mais pura tradição orgíaca das bacantes, emerge da cena social e intelectual de uma Paris fin-de-siècle para desencadear, contra todas as convençóes, o conceito de arte da volúpia ou da volúpia como arte, muito antes que do simples exercício da voluptuosidade na arte. Revertendo até à radicalidade o modelo platônico da escala do amor, essa estranhíssima figura da "americana" - singularmente nunca nomeada, a não ser por sua algo extravagante referência de origem num contexto europeu, $\mathrm{e}$ que surge na trama táo inopinadamente quanto se desvanecerá - adentra, qual nova Diotima, a comunidade intelectual masculina da boemia parisiense com o objetivo de inscrever conceitualmente a definiçáo de volúpia como o mais alto grau de uma espiritualidade corpórea, o espasmo mais sofisticadamente consentido de uma refinadíssima e espiritualizante erótica, cujo fundamento imagético seria a sinestesia, essa conjunção inesperada de sensaçóes que se confundem para realizar o que nenhum sentido isoladamente é capaz de isoladamente conseguir.

Do lado oposto da luxúria, dos amplexos brutais, dos beijos úmidos, das carícias repugnantes e viscosas, essa voluptuosidade é a experiência da con-fusão radical dos sentidos que escapam, aliás, a qualquer configuraçấo referencial, por se constituírem antes como intangibilidades que ligam, num mesmo excesso, a sensorialidade e a espiritualidade, $o$ desejo e a morte, Eros e Thanatos, como opostos que coabitam. Como traduzir esse fremir em espasmos de aurora, em êxtases de chama, ruivos de ânsia? Baudelairianamente, esse mundo em que convergem o sensorialismo mais radical e o gozo mais refinado do espírito é aquele em que "os perfumes, as cores e os sons se respondem". E se os frescos perfumes podem ser doces como oboés, ao lado deles insinuam-se os outros, corrompidos, ricos e triunfantes, como o âmbar, o almíscar, o benjoim e o incenso, que se expandem em embriaguez do espirito e dos sentidos, compondo enfim um mundo onde tudo parece participar de uma tenebrosa e profunda unidade, oximoro que aproxima adjetivos voluntariamente contraditórios em que se inscrevem a magnitude e o terror. E é em linguagem que essa embriaguez se cria, tal como o fizera já o poeta das "Correspondências" no referido soneto em alexandrinos que ganharam o mundo como uma arte poética simbolista. 
A “americana” é, portanto, a Diotima de Sá-Carneiro, para quem a espiritualização da volúpia seria o estágio mais sublime da beleza ideal, dos "desejos espiritualizados em beleza". Na sua sedutora e fascinante pedagogia, dela se ouve a lição da volúpia das correspondências sinestésicas em que se cruzam impressóes de planos diversos: o físico e moral, o concreto e o abstrato, o sedutor e o terrificante, identificados pela voluptuosidade do fogo, a perversidade esguia da água, os requintes viciosos da luz. Ouçamo-la:

\begin{abstract}
Ah! mas aquele que fosse um grande artista e que, para matéria-prima, tomasse a voluptuosidade, que obras irreais de admiráveis náo altearia!... Tinha o fogo, a luz, o ar, a água, e os sons e as cores, os aromas, os narcóticos e as sedas - tantos sensualismos novos ainda não explorados... Como eu me orgulharia de ser este artista!... E sonho uma grande festa no meu palácio encantado, em que os maravilhe de volúpia... em que fizesse descer sobre vós os arrepios misteriosos das luzes, dos fogos multicolores - e que a vossa carne sentisse enfim o fogo e a luz, os perfumes e os sons, penetrando-a a dimaná-los, a esvaí-los, a matá-los!... Pois nunca atentaram na voluptuosidade do fogo, na perversidade esguia da água, nos requintes viciosos da luz?... Eu confesso-lhes que sinto uma verdadeira excitaçáo sexual - mas de desejos espiritualizados em beleza - ao mergulhar as minhas pernas todas nuas nas águas dum regato, ao contemplar um braseiro incandescente, ao deixar o meu corpo iluminar-se de torrentes eléctricas, luminosas... Meus amigos, creiam-me, não passam de uns bárbaros, por mais requintados, por mais complicados e artistas que presumam aparentar.
\end{abstract}

(CL, p.20-21)

Trata-se de um discurso autonímico, naquele sentido em que não apenas refere o erotismo mas é ele mesmo eroticamente constituído, com os êxtases prosódicos da pontuação exaltada, das sinestesias radicais, dos paralelismos sintáticos, do ritmo acelerado pelas enumeraçóes consecutivas, que só teria igualha no espírito de "um grande artista" e nunca nos bárbaros requintados que apenas se presumissem artistas. Nova concepção de volúpia, portanto, e nova concepçáo de arte. Trata-se de um saber pessoal, só passível de ser evocado no nível do desejo, posto que a possibilidade de sua existência demanda um criador ainda por vir ("Como eu me orgulharia de ser este artista!..."), que dispusesse dos meios adequados para ultrapassar em gesto essa etapa da enunciação, em outras palavras, da sua tangibilidade em ato verbal.

\title{
Da encenaçáo:
}

Finda, portanto, a lição teórica, o segundo passo dessa inusitada personagem feminina seria o de transformar o conceito que veiculara verbalmente em grande festa. Mas festa aurática, nunca grotesca, festa de apagamento dos limites, em que o mundo masculino do dandysmo mergulha como simples espectador de uma incorpórea fisicalidade de refinadíssimos sentidos.

Cabe a Lúcio, narrador da novela e espectador da festa, fazer o relato dos seus efeitos, através de uma descrição sensorialmente minuciosa da qual não se afasta nunca a sensação do assombroso, do teatral e do onírico: 


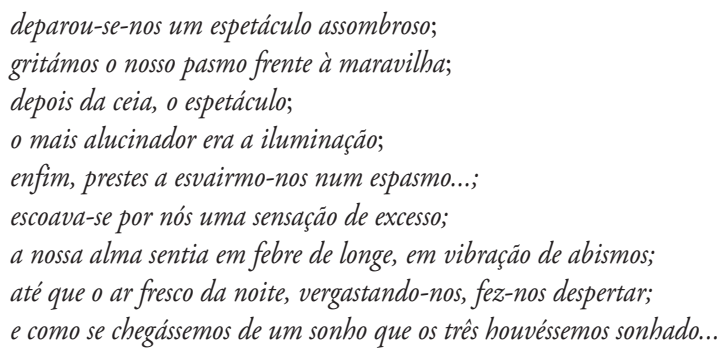

Nessa festa orgíaca em que se combinam a sensualidade do voyeurismo e o êxtase do voyant - que Rimbaud definira como "um desmesurado e consciente desregramento dos sentidos" - são justamente postos em cena pela estranhíssima personagem da "americana" os projetos verbais de uma arte da volúpia, antes que, com uma incoerência apenas aparente, ela própria desaparecesse daquele cenário de magia, tăo misteriosamente quanto surgira, tal qual Diotima no circuito homofilicamente masculino do banquete de Platáo.

A festa é uma cena de teatro de fulguração homoerótica, com mulheres a funcionarem como actantes secundárias dos excessos experimentados pela "americana", aquela afinal sobre quem todos os olhares convergem e cujo orgasmo final metaforiza-se como desaparecimento e morte.

Então foi apoteose:

Toda a água azul, ao recebê-la, se volveu vermelha de brasas, encapelada, ardida pela sua carne que o fogo penetrara... E numa ânsia de se extinguir, possessa, a fera nua mergulhou... Mas quanto mais se abismava, mais era lume ao seu redor...

...Até que por fim, num mistério, o fogo se apagou em ouro e, morto, o seu corpo flutuou heráldico sobre as águas douradas - tranquilas, mortas também.

A morte da "americana" se consuma no mistério do fogo - vermelha de brasas, encapelada, ardida; na ascensão radical - corpo heráldico que flutua; em brilho ofuscante - fogo que se apaga em ouro, etapa final da transmutação alquímica do tangível.

\section{Da experimentaçáo:}

Como a demonstraçáo de uma tese que se preparara em conceito e mise-en-scène, os fatos que se seguem à cena da festa constituirão a fase da experimentação, na escala individual, dos êxtases e dos mistérios que compóem, afinal, o enredo da narrativa da confissão de Lúcio. Passar do inefável para a linguagem é possivelmente o seu modo de

\footnotetext{
2 "un immense et raisonné dérèglement de tous les sens": Arthur RIMBAUD, "Lettre de Rimbaud à Paul Demeny", le 15 mai 1871. Oeuvres Complètes, Pléiade, p.249.
} 
tentar perceber com outras categorias - que não as da racionalidade - o exercício dessa erótica transgressora.

A experiência homoerótica feminina - maravilha / mirabilia para espectadores eleitos - é o que dará suporte à experiência de afeto dos dois protagonistas masculinos - Lúcio e Ricardo de Loureiro - cuja atração mútua, travestida de amizade, só logrará completar-se com o advento algo surpreendente de Marta, terceiro elemento - já agora feminino - que será o modo de normalizar, ou de normatizar, uma transgressão homoerótica através de uma outra transgressão de base psicótica que consiste na produçáo de um suplemento de personalidade, de um desdobramento da psique na imagem de um duplo de si.

Tomado o aparecimento de Marta no limite do fantástico, poder-se-ia aventar que estaríamos diante de uma estratégia perversa (no seu sentido etimológico de vertida ao contrário, logo, travestida) para autorizar a transgressão de um interdito sexual, de modo que a circulação dos desejos se fizesse triangularmente através de uma figura criada numa dimensão onírica que, até ao fim, se mantém impermeável a explicaçóes racionalizáveis. Essa leitura da novela na linha do evento sobrenatural será possivelmente o caminho mais convencional de interpretação, na medida em que a opçáo pelo fantástico negligencia, por princípio, qualquer tentativa explicitação referencial.

O fato de caber a Lúcio o ponto de vista da trama facilita, aliás, essa vertente que desloca para um plano não realista as inquietaçóes do personagem, já que o surgimento de Marta na relaçáo que o unia a Ricardo de Loureiro parece-lhe sempre descrito como se acontecido fora de si, num conjunto de estranhos fatos que se transformaram para ele em pura evidência e de cuja fisicalidade ele não consegue abdicar. Marta está ali, vive consistentemente no presente, fala, tem opinióes - sejam elas em tudo o espelho das ideias de Ricardo - solicita-o, deseja-o, ama-o. As dúvidas que sobre ela pairam, advindas, por exemplo, do seu aparecimento inesperado como mulher institucionalmente casada com Ricardo, ou da falta de referências identitárias (origem, relaçóes familiares, atividades profissionais) que parece sugerir nela uma ausência de passado, não chegam a desnorteá-lo, possivelmente porque não lhe interessaria investigar mais profundamente uma situação até certo ponto satisfatória para a realização dos seus desejos até então contidos e recalcados. E é assim, com altos e baixos na sua credibilidade, que Lúcio prefere neutralizar as dúvidas sobre a figura de Marta optando por crer na sua consistência vital que, de modo algo redentor, fizera sanar o interdito da paixáo através de um suposto adultério (Marta estava casada com Ricardo) que gozava, estranhamente, do consentimento das partes afetadas.

Outra hipótese de leitura da novela seria a de entender a trama do duplo no plano da pura criação ficcional, em outras palavras, como metáfora. Nesse caso Marta passaria a ser tão somente o modo concreto da dimensão feminina do corpo masculino de Ricardo, permitindo a completude da fisicalidade homoerótica e viabilizando o impasse anteriormente enunciado: "Mas uma pessoa do nosso sexo náo a podemos possuir”, impasse na verdade só aparente, já que desde então ele próprio aponta o sor- 
tilégio de sua ultrapassagem: "Logo eu só poderia ser amigo duma criatura do meu sexo, se esta criatura ou eu mudássemos de sexo" (CL,55).

A opção pela narrativa em primeira pessoa cria contudo alguns problemas de interpretaçáo. Lúcio, que reitera sempre a verdade da sua "confissão", em nenhum momento se refere a essa ficcionalização consentida, preferindo manter, no avesso de um registro explícito (fosse ele metafórico), a indecidibilidade dos fatos quer no que tange ao desfecho da tragédia (morte, desaparecimento, condenaçáa) quer no que se refere à possibilidade de desvelamento do mistério da triangulação amorosa. Sendo assim, ou se inviabilizaria a credibilidade do narrador ou essa concepçáo de um duplo como registro apenas metafórico se revela estruturalmente insustentável.

Freud afirmara que o duplo nasce do "terreno do ilimitado amor a si próprio, do narcisismo primário". E continua: "Com a superação dessa fase, o duplo tem seu sinal invertido e de garantia de sobrevivência passa para inquietante mensageiro da morte". Amor e morte reunidos de modo visceral.

A consistência da realidade do duplo só viria a ser desfeita verbalmente nos últimos capítulos da novela quando, depois de uma crise passional em que se misturam o ciúme, a inveja, e o desprezo, Ricardo revela a Lúcio aquilo que Marta afinal seria. Desde entấo, desvelada como criação sua, como a sua grande obra de arte, a sua obra-prima plenamente conseguida, Marta aparecerá pela primeira vez "explicada", o que, obedecendo à configuração mais tradicional do duplo, é o responsável por detonar imediatamente o processo de sua necessária eliminação.

Pois é justamente sobre essa versão do advento do duplo narcísico, trazida enfim à cena como epifania da paixão, que me interessa pensar aqui. Ela estará necessariamente centrada no relato em primeira pessoa de Ricardo, mesmo que daí náo se ausente a consciência de que essa transcrição em discurso direto do personagem se insere na narrativa da "confissão" de Lúcio. A apreensão da mesma experiência pelo narrador da novela será evidentemente outra, comprometida que sempre esteve por um consentimento pouco mobilizado pelas causas e mais interessado nos efeitos, o que o levou a não contrariar a discutível verossimilhança de Marta como sujeito e realidade independentes do verdadeiro parceiro de seus afetos náo consumados.

O duplo de configuração narcísica é recorrente na literatura. A visibilidade desse tema ${ }^{4}$ atravessa tempos e autores com constantes e variantes tais como a sombra como alma, a figura dos gêmeos, o pacto com o demônio, a dupla personalidade, o sonho de rejuvenescimento, a demanda de eternidade, a crença na dupla paternidade, o desejo de morte. Na leitura de A Confissão de Lúcio o mito de Narciso ganha contornos relevantes e nos convida a interpretar o modo como Sá-Carneiro negocia com ele, como o relê, como dele se apropria e o transforma em uma dominante da configuração da

\footnotetext{
${ }^{3}$ FREUD, "O inquietante". Obras completas, vol 14, Sáo Paulo, Cia das Letras, 2010, p. 352. Em algumas traduçōes o título aparece como "O estranho".

${ }^{4}$ Cf Otto Rank. Don Juan et le Double. http://classiques.uqac.ca/classiques/rank_otto/don_juan/rank_donjuan_double.pdf
} 
personagem de Ricardo de Loureiro, em que estarão presentes duas de suas variantes: a história do reflexo perdido 5 e a necessidade da morte do outro.

Nesse ensaio sobre a voluptuosidade que parece ser uma via de leitura para a novela de Sá-Carneiro, a evidência do investimento na beleza é uma tônica da experiência dos sujeitos para assegurarem, através dela, o gozo, a paixão, a sedução. Acrescente-se a isso o fato de esses personagens, não por acaso, serem todos artistas, conscientes de sua fúria criadora, mesmo que em geral improdutiva, que se negam a qualquer compromisso utilitário em nome de uma grandeza superior que ultrapassa o senso comum da experiência em sociedade, e a seduçáo da beleza assim como a capacidade de a produzir - mente bela em corpo belo - parecem ir de par com a estrutura mesma do narcisismo

A volúpia da beleza é, no caso de Narciso - terreno do mito e de suas migraçóes conceituais -, uma vocação autocentrada e autotélica, já que nele a paixão não se dirige a um outro diferente de si ou seu complementar na esfera dos valores, mas à sua própria imagem, sem qualquer sentido ou finalidade para além ou fora de si. Narciso seria assim a radicalização e a realização mais perfeita da poética asserção neoplatônica do "Transforma-se o amador na coisa amada", que Camóes herda de Petrarca mais para o contradizer do que para nele se espelhar, e finalmente para o refutar numa argumentação que o inviabiliza. ${ }^{6}$ Só que Narciso não leu Camóes, aquele que lhe deu a volta por não querer abdicar do arriscado mas sedutor conhecimento do outro como diferente de si: "Não canse o cego Amor de me guiar a parte donde não saiba tornar-me". Narciso, ao contrário, permanece em si, confina-se ao mesmo, sacrifica Eco a um destino de trágica solidão, até que o processo de autocontemplação lhe reserve, também a ele, o salto para a morte, condenado pelo fascínio da própria imagem, seu duplo no espelho das águas.

A questão metodológica que aqui se póe é contudo a seguinte: como aproximar de Narciso a figura de Ricardo de Loureiro? Em que variante situar essa projeção de um personagem masculino numa figura feminina que tem, já sexualmente, a marca de uma diferença? A fala do personagem será, nesse caso, o caminho mais autorizado para a revelação ampliada do seu narcisismo pois que constituído pela idolatria nascida de uma autocontemplação voluptuosa, não através de uma miragem no espelho da identificação, mas na possibilidade de produção de um outro ainda mais perfeito de si (passe a tautologia etimológica), no desejo de sentir-se outro sendo o mesmo, nesse caso um desejado outro feminino.

\footnotetext{
${ }^{5}$ Cf Hoffman. "L'histoire du reflet perdu", tomo II, cap. III, dos Contos fantásticos. Mas seria um excelente desenvolvimento da pesquisa revisitar autores brasileiros como Machado de Assis ou Guimaráes Rosa. Em ambos os casos, "O espelho", de Papéis avulsos, e o conto medial das Primeiras estórias, com o mesmo título do anterior, podem bem fundamentar em metáfora a perquirição sobre a identidade do sujeito,

${ }^{6}$ Refiro aqui a leitura do soneto "Transforma-se o amador na coisa amada", proposta por Helder Macedo em Camóes e a viagem iniciática, ensaio publicado em 1980 (Lisboa) e republicado no Brasil pela Móbile (2013) e em Portugal pela Abysmo (2013).
} 
"Ah! meu querido Lúcio [..] como eu sinto a vitória duma mulher admirável, estiraçada sobre um leito de rendas, olhando a sua carne toda nua...esplêndida...loira d'álcool! A carne feminina - que apoteose! [..] E lembra-me entáo um desejo perdido de ser mulher - ao menos para isto: para que num encantamento pudesse olhar as minhas pernas nuas, muito brancas, a escoarem-se, frias, sob um lençol de linho".

Ricardo de Loureiro viabiliza nessa utopia um só aparente deslocamento para o outro. O seu verdadeiro investimento está na criação de uma autoimagem aperfeiçoada, que embora não seja, como refere o mito, a do seu reflexo, é ainda a da sua projeção ideal, o que só amplia o gozo de si na competência dessa transmutação, radicalizando o gozo narcísico. Quando ele expóe a Lúcio o seu fascínio pelo corpo feminino - "mulher admirável, estiraçada sobre um leito de rendas, olhando a sua carne toda nua ... esplêndida ... loira de álcool" - estamos longe de assistir a uma dissociação ou mesmo a uma alterização do objeto do desejo. O que seria verdadeiramente belo - e nesse sentido verdadeiramente desejável - era o seu "desejo perdido de ser mulher" para se poder mirar como tal, e "num encantamento pudesse olhar as [..] pernas nuas, muito brancas, a escoarem-se, frias, sob um lençóis de linho", numa convergência de excessos de sensaçôes visuais, (nuas, brancas), de percepçôes táteis (frias, linho), de uma liquidez (escoarem-se) que lembra a dissoluçáo de toda concretude.

Construía-se já ali, nessa confissão do desejo de sentir-se mulher pelo culto do belo, a sua estratégia futura de invenção da personagem de Marta como seu duplo, uma espécie de embriáo heteronímico, que Mário de Sá-Carneiro algumas vezes tangencia, e que Fernando Pessoa realizaria na sua radicalidade como modo de sentir tudo de todas as maneiras.

Marta é esse duplo construído como projeção de uma beleza ideal que o corpo masculino desejoso de feminizar-se logra constituir. Nessa linha de leitura justificar-se-iam algumas cenas absolutamente exemplares que apontam o espelhamento constitutivo das duas personagens - Marta e Ricardo -, em que a consistência afetiva de um é inversamente proporcional ao desvanecimento do outro, ao desvelamento da sua inconsistência histórica e, por que não, jurídica.

Na primeira delas Lúcio, que observa Marta numa sala de concerto, a vê desaparecer do seu campo de visáo no exato momento em que Ricardo é tomado por um excesso de emoçâo diante de um concerto muito significativamente chamado Além. ("Nunca vibrei sensaçóes mais intensas [dirá ele] do que perante esta música admirável”- CL, 67) . Narrada por Lúcio a cena é a seguinte:

E entâo, pouco a pouco, à medida que a música aumentava de maravilha, eu vi - sim na realidade vi! - a figura de Marta dissipar-se, esbater-se, com a som a som, lentamente, até que desapareceu por completo. Em face dos meus olhos abismados eu só tinha agora o fauteuil vazio...(CL, p.66-67)

A segunda cena é como um reflexo invertido da primeira, e tem a ver com o momento em que Ricardo de Loureiro, no auge da paixáo entre Lúcio e Marta, e, nesse sentido, no auge daquilo que ele imaginava ser a grande vitória da sua alterização, 
relata ao amigo o que chamou de "uma bizarra alucinação" (CL,77): "Por acaso olhei para o espelho do guarda-vestidos e não me vi reflectido nele! Era verdade! Via tudo em redor de mim, via tudo quanto me cercava projectado no espelho. Só não via a minha imagem!" (CL,77). Marta sobrepujava-se ao seu criador, e a máscara da personagem encobria ou anulava a face do seu autor.

A explicação de ambos os fenômenos parece absolutamente coincidente com o modelo esperado do fenômeno do duplo: em momentos de excesso de afeto ou de emoção por parte de um, a imagem do outro perde consistência e desaparece - e, no entanto, um detalhe não despiciendo vem roubar-nos a certeza sobre essa hipótese de entendimento. Se a primeira cena é narrada por Lúcio a segunda não o é, na verdade, menos, pois transita daquilo que seria uma declaração verdadeira de Ricardo sobre uma experiência pessoal de caráter, digamos, sobrenatural (já que para ele inexplicada) para uma possível irrealidade do discurso e, nesse sentido, para a diluição do seu valor de verdade. $\mathrm{O}$ que equivale a dizer que ambas as cenas de perda de imagem são na verdade percepçóes de Lúcio, credíveis na dimensão da parcialidade do seu ponto de vista:

"Porém, refletindo melhor, descobri que em realidade o meu amigo não me dissera nada disto. Apenas eu - numa reminiscência muito complicada e muito estranha - me lembrava, não de que verdadeiramente ele mo tivesse dito, mas de que, entretanto, mo devera ter dito" (CL, p.77).

O que parece evidente tanto no mito de Narciso, como no conceito de narcisismo para Freud, a respeito da imagem do duplo como modo de representação do eu, é a convivência de afetos contraditórios em que a fascinação vem assinalada pela tensão entre a aspiração por um ideal (seja ele a beleza ou a eternidade ou o poder) e o ódio avassalador, que tende frequentemente à eliminaçáo e à morte, pelo fato de o duplo, na sua autonomizaçáo, ser pressentido como franca ameaça à identidade do sujeito.

Ricardo desejara-se mulher, lograra mesmo projetar-se num corpo feminino que, relembrando a categoria do "estranho"8 (unheimlich) para Freud, é mais do que a evidência imediata do não familiar ou do não doméstico, mas vem investido de uma dimensão ambígua que desfaz a simplicidade das oposiçóes para se reconhecer também

\footnotetext{
${ }^{7}$ Sobre esse epifenômeno, Otto Rank (1932) refere, entre outros tantos exemplos mais ou menos contemporâneos da novela de Sá-Carneiro, o filme "O Estudante de Praga" de Hans Heinz Ewers, em que Balduin, depois de um pacto fáustico, aceita que lhe roubem a sua sombra até que ela reiteradamente reaparece diante dele como seu duplo macabro, destituindo-o dos seus afetos. Ao perceber que já não é capaz de ver a sua imagem no espelho, atira no fantasma e morre do mesmo tiro. Já no conto "Le Horla" de Maupassant, o personagem sem causa aparente (o que redobra a angústia e o sentimento de absurdo) se expóe a alucinaçóes sucessivas ao se sentir perseguido por uma espécie de fantasma de si próprio, vê sua própria imagem desaparecer no espelho do quarto, e, ao tentar eliminar a figura incorpórea pelo fogo, destrói inutilmente a casa, torna-se o assassino dos criados que ali ficaram aprisionados, até concluir que, contrariamente a si mesmo, exposto humanamente à morte a cada instante, le Horla, "corpo feito só de Espírito, não precisava temer nem os males, nem os ferimentos, nem as enfermidades, nem a destruição prematura".
}

${ }^{8}$ FREUD, S. (2010, p. 338). 
como aquilo que deveria ter permanecido oculto, quieto, tranquilo (heimlich) mas que ousou apresentar-se à luz revelando sua estranheza (unheimlich). Daí o medo e o horror que impulsionam à morte. Mas ao destruir o outro (o duplo, o estranho que veio à luz) é também quase sempre a si que o sujeito destrói. Como uma fatalidade, na luta pelo objeto do desejo, alguém precisa morrer.

Apontar essa versão do duplo narcísico na novela de Sá-Carneiro é mais do que somar uma nova variante de leitura para entender o surgimento do personagem de Marta para além da versão digamos sobrenatural ou da estratégia de ficcionalização metafórica. A opção pelo tratamento do narcisismo torna-se sobretudo funcional para intuir uma interpretação mais consequente para o desfecho da novela que, na camada mais objetiva do discurso, finda sobre a afirmação de Lúcio sobre a sua inocência. Narrada sem a intervenção de um narrador onisciente, fica-se a saber táo somente a versão de Lúcio, que vem contudo comprometida por uma supressão momentânea da sua própria lucidez e, nesse sentido, por uma incapacidade de julgamento imparcial e objetivo. Acumulam-se significantes tais como assombro, mistério, aterrado, possesso de medo, olhos fora das órbitas, cabelos erguidos, precipitar-se, carreira louca. (CL, 122-3). Depois de um hiato composto visualmente por duas linhas de pontos de suspensão, ele acrescenta ainda: "- Quando pude raciocinar, juntar duas ideias, em suma quando despertei deste pesadelo alucinante que fora só a realidade, a realidade inverossimil - achei-me preso num calabouço do Governo Civil[...] (CL, 123 grifos meus)

Resumidamente é essa a versão de Lúcio: depois de Ricardo lhe ter revelado o segredo da invenção de Marta, depois de ter admitido que através dela pudera realizar seu afeto não apenas por Lúcio mas pelo russo Sergio Warginsky, ${ }^{9}$ o criador decide eliminá-la com um tiro. Marta entáo desaparece, o corpo de Ricardo cai, Lúcio tem o revólver ao seu lado e será condenado por homicídio e a dez anos de prisão.

Esses dez anos esvoaram-se-me como dez meses. É que, em realidade, as horas não podem mais ter ação sobre aqueles que viveram um instante que focou toda a sua vida. Atingido o sofrimento máximo, nada já nos faz sofrer. Vibradas as sensaçôes máximas, nada já nos fará oscilar. Simplesmente, este momento culminante raras são as criaturas que o vivem. As que o viveram ou são, como eu, os mortos-vivos, ou - apenas - os desencantados que, muita vez, acabam no suicídio. (CL, p.12)

Ricardo-Narciso poderia assim justificar o desenlace da trama em que o assassinato do segundo eu corresponde regularmente à morte do herói: assassinar o duplo

\footnotetext{
${ }^{9}$ Era um belo rapaz de vinte e cinco anos, Sergio Warginsky. Alto e elançado [...] Os seus lábios vermelhos, petulantes, amorosos [...] Os seus olhos de penumbra áurea, nunca os despregava de Marta - devia-me lembrar mais tarde. Enfim, se alguma mulher havia entre nós, parecia-me mais ser ele do que Marta. [...] Sergio tinha uma voz formosíssima - sonora, vibrante, esbraseada. [...] Por isso Ricardo se aprazia muito em lhe mandar ler os seus poemas que, vibrados por aquela garganta adamantina, se sonorizavam em auréola. [...] De resto era evidente que o poeta dedicava uma grande simpatia ao russo. A mim, pelo contrário, Warginsky só me irritava - sobretudo talvez pela sua beleza excessiva -, chegando eu a náo poder retrair certas impaciências quando ele se me dirigia.
} 
torna-se uma variante fatal do suicídio. O mistério do duplo está todo explicitado no fundamento identitário que origina a sua criação: "Compreendemo-nos tanto, [confessa Ricardo a Lúcio] que Marta é como se fora a minha própria alma. Pensamos da mesma maneira, igualmente sentimos, Somos nós-dois".(CL, p.120).

Para além dessa especularidade, Marta havia sido para Ricardo a quintessência do poder, de tal modo que à seduçấo narcísica se soma o fascínio fáustico de ultrapassagem de seus próprios limites sobre uma incapacidade - aliás pouco justificada na dimensão meramente física - de possuir uma pessoa do mesmo sexo. É pois num transe de transmutação que aquele ouro desejado pelos alquimistas, a remeter à cena da teatralizada da "americana", pareceu-lhe de súbito viável, tangível, realizado. Como se maldição fálica do seu corpo masculino não precisasse violar-se ou abdicar de si para tornar-se corpo penetrável, já que um duplo feminino ocupava esse lugar ao reunir complementarmente - e não paradoxalmente - a semelhança e a diferença. Era a revelação do "grande segredo", a sua apoteose:

Uma noite, porém, finalmente, uma noite fantástica de branca, triunfei! Achei-A... sim, criei-A!... criei-A... Ela é só minha - entendes? - é só minha!... Compreendemo-nos tanto, que Marta é como se fora a minha própria alma. Pensamos da mesma maneira; igualmente sentimos. Somos nós-dois... Ah! e desde essa noite eu soube, em glória soube, vibrar dentro de mim o teu afeto - retribuir-to: mandei-A ser tua! Mas, estreitando-te ela, era eu próprio quem te estreitava... Satisfiz a minha ternura: Venci! E ao possuí-la, eu sentia, tinha nela, a amizade que te devera dedicar - como os outros sentem na alma as suas afeiçóes. Na hora em que a achei - tu ouves? - foi como se a minha alma, sendo sexualizada, se tivesse materializado. E só com o espírito te possuí materialmente! Eis o meu triunfo... Triunfo inigualável! Grandioso segredo!...

E quanto a Lúcio? Se acreditarmos nele, contentar-nos-emos com a sua lógica delirante cujos valores ficam claramente explicitados: não se defende das acusaçôes de homicídio embora afirmando-se inocente depois de dez anos de reclusão; não se desespera com a condenaçáo; aceita como um privilégio ser no presente um morto-vivo por ter tido um dia o vislumbre da plenitude. Se se crê nele como narrador, é esta a história.

Há porém um detalhe singular, uma pista policial que compromete imageticamente Lúcio com a morte de Marta, e que nasce, malgré lui, num gesto passível de leitura psicanalítica, do seu próprio discurso, discurso que o faz antes de ser feito por ele, já o sabemos. Detalhe não desprezível, Lúcio, escritor impotente, escrevera uma peça (que ele tinha ainda por inacabada) cuja encenação teria sido prometida para os palcos de Lisboa apontando assim para um seu possível triunfo. Às vésperas da primeira representação, imbuído o seu autor de uma fúria de inspiração, anuncia ao metteur-en-scène uma nova proposta de desenlace para a peça. O que ela é, o que a alteraçáo representa não ficamos a sabê-lo com clareza para além do fato de na primeira versão morrer o personagem do escultor e de a segunda versão - que Lúcio julgava "uma ideia belíssima, grande, que [o] entusiasm[ava]"(CL, 115) - ter sido julgada pelo empresário 
"um disparate". O fato é que Lúcio recusa a montagem já feita e, como não consegue persuadir o metteur-en-scène da superioridade da sua nova versão, lança o manuscrito da sua obra - cujo título é $A$ Chama - para dentro de uma fogueira, destruindo-a: a Chama na chama, espécie de fatalidade tautológica. Falha o artista incompleto por não deixar vir à luz a sua obra-prima, condenando-a inexoravelmente ao silêncio, ao fogo, à morte.

Essa cena sacrificial antecede imediatamente o paroxismo da relação entre Lúcio e Ricardo e o que salta aos olhos é a função de mise en abyme em que a peça afinal não representada antecipa em metáfora o desenlace da novela, táo elíptica uma quanto a outra, mas nas suas exíguas referências absolutamente referenciáveis, já que ambas apostam antes numa soluçáo realista - assassinato do personagem (escultor na peça, Ricardo na novela - "me voou pelo cérebro a ideia rubra de o assassinar"(CL, 111) evoluindo ambas paralelamente - peça e novela - para qualquer coisa de mais ambígua, um "disparate" (para falar como o empresário) ou, nas palavras de Lúcio, para um "acto novo [...] profundo e inquietador" que "rasgava véus sobre o além"(CL,117). Façamos pois o esforço de conviver com a ambiguidade na leitura, não da peça a que não temos acesso nem no momento em que Lúcio a lê a pedido de Ricardo, nem $a$ posteriori com a falência da representaçáo e a consumição pelo fogo, mas da novela que, afinal, também finda em apoteose do fogo. Essa simbiose está aliás inscrita no discurso de Lúcio: "sugerira-se-me durante a leitura outra ideia muito estrambótica. Fora isto: pareceu-me vagamente que eu era o meu drama - a coisa artificial - e o meu drama a realidade"(CL,102)

Recorde-se que no momento em que recebera o convite efusivo para a montagem da sua peça nos teatros de Lisboa, Lúcio rompera sua relaçáo com Ricardo por razóes ambíguas: ciúmes de Marta com outros possíveis amantes, desprezo por Ricardo "em face da sua baixeza" no consentimento das múltiplas traiçóes da mulher, e inveja. E desesperado afirma: : "me voou pelo cérebro a ideia rubra de o assassinar - para satisfazer a minha inveja, o meu ciúme, para me vingar dele"(CL, 111). Se o ciúme e a vingança são facilmente explicáveis, a inveja carrega em si uma maior complexidade, uma estranheza, uma bizarrice: ao asco e ao ódio por Ricardo se mescla a um outro afeto, a inveja, aquele desejo de ser o que o outro é, de ter o que ele possui. Nesse caso, o que Ricardo possuía era uma face feminina que podia pertencer a muitos homens: "Invejava-o! Invejava-o por ela me haver pertencido... a mim, ao conde russo, a todos mais!..." O que dilacerava Lúcio era portanto mais que o ciúme de Marta, era mais que desejo de vingança que abria nele a brecha do assassinato de Ricardo. Era a inveja de o outro ter publicamente acedido a formas diversas do prazer, ao gozo multiplicado com outros homens, através de uma obra verdadeiramente conseguida de outrar-se no feminino. Enquanto a ele, Lúcio, coubera-lhe tâo somente dessa Marta uma fulguração feminina que ele fora incapaz de possuir. Ricardo a triunfar em Marta. Marta a escoar pelos dedos de Lúcio, como mera "reminiscência longínqua", logrando táo somente 
uma aventura passageira, o que é, aliás, uma reverência intertextual à "passante" 10 de Baudelaire, a ponto de o poema das Flores do mal poder servir quase verso a verso como uma interpretação da fugacidade de sua experiência: fugitiva beleza, majestade, fausto, nobreza, agilidade, relâmpago e noite, olhar livido onde nasce o furacão, dor que fascina e prazer que mata. Diante dela Lúcio, como o poeta, de repente renasce, ao mesmo tempo que dela tudo ignora, ela que ele teria amado, ela que o sabia.

Ouçamos o texto

Com efeito, ainda hoje, às tardes maceradas, eu não seu evitar uma reminiscência longínqua, a saudade violeta de certa criaturinha indecisa que mal roçou a minha vida. Por isso só: porque ela me beijou os dedos; e um dia, a sorrir, defronte dos nossos amigos, me colocou em segredo o braço nu, mordorado, sobre a mão... E depois logo fugiu da minha vida, esguiamente, embora eu, por piedade - doido que fui! - ainda a quisesse dourar de mim num enternecimento azul pelas suas caricias (CL, 108)

Como a tornar mais complexa a relação triádica dos personagens, revelam-se aí uma série de duplos consecutivos, especulares e complementares, de tal modo que qualquer um dos elementos está em íntima conexáo com os demais, dependendo dos três o seu precário equilíbrio: Ricardo quer ser Marta e logra sê-lo, realizando o desejo de ser mulher e de possuir outros homens; Lúcio possui uma Marta que se dissolve numa reminiscência longínqua no falhado trânsito afetivo de seu desejo por Ricardo; Lúcio enfim que ser Ricardo, inveja-o, naquilo que vai intuindo como o gozo conseguido da sedução.

Resta voltar a Marta e ao seu desaparecimento que, na linha da fatalidade narcísica e autodestrutiva de Ricardo de Loureiro, parecia ter ganho contornos bastante justificáveis. Mas se é assim, onde localizar, no paralelo com a peça não representada de Lúcio, aquela dominante profunda e inquietadora que rasgava véus sobre o além? Passemos pois aos discursos que é o lugar da traição dos segredos. Na narrativa de Lúcio sobre a morte de Marta denuncia-se inconscientemente uma outra lógica, como

${ }^{10}$ La rue assourdissante autour de moi hurlait. / Longue, mince, en grand deuil, douleur majestueuse, / Une femme passa, d'une main fastueuse / Soulevant, balançant de feston et l'ourlet. // Agile et noble, avec sa jambe de statue. I Moi je buvais, crispé comme un extravagant, / Dans son ail, ciel livide où germe l'ouragan, / La douleur qui fascine et le plaisir qui tue. // Un éclair... puis la nuit! - Fugitive beauté / Dont le regard m’a fait soudainement renaître, / " ne te verrai-je plus que dans l'éternité? I/ Ailleurs, bien loin d'ici! trop tard peut-être! / Car j'ignore où tu fuis, tu ne sais où je vais, I o toi que j'eusse aimée, ô toi qui le savais!

O fascínio do poema de Baudelaire "A une passante" (Les Fleurs du Mal) gerou outras cenas poéticas nele inspiradas como "A débil" de Cesário Verde, aquela com quem o poeta se compraz, náo pela suavidade que fascina e pelo prazer que mata, mas por intuir nela o poder nascido de uma inteireza moral, de uma força natural e de uma pureza rural, elementos capazes de contaminar positivamente a doença de uma metrópole ameaçadora. Tão diversas e tão similares, são ambas passantes, fugazes, alumbramentos, como em reminiscência Marta aparecera para Lúcio.

Acentue-se aqui, como um parêntesis, que Baudelaire e Cesário Verde eram dois poetas que estavam evidentemente no horizonte das expectativas literárias de Sá-Carneiro, de tal modo que não parece aleatória a evocação da "passante" e da "débil" na composição "criaturinha indecisa que mal [lhe] roçou a vida". 
um ato falho denunciador: "Marta, essa desaparecera, evolara-se em silêncio, como se extingue uma chama..." Como se extingue uma chama. Caberá entâo perguntar: tal como a peça de teatro se extinguira por ter sido jogada ao fogo pelo autor desiludido, transformando-se ele no motor da sua própria perdiçấo? Depois da peça de teatro seria agora a vez de Marta também morrer pelo fogo / chama do revólver por decisão de Lúcio? A arma de fogo, que inexplicavelmente (é o que sugere a sua confissão de inocência) estava ao lado dele na hora da morte de Ricardo, impedindo de sua parte qualquer defesa que o isentasse de uma culpa demasiado evidente, deixaria de ser assim mais que um acaso assombroso ("E aos meus pés - sim, aos meus pés! - caíra o seu revólver ainda fumegante"- CL, 122), mas uma outra versáo do mesmo ato simbólico de eliminar pela chama a inadequação insuportável dos afetos, sejam eles ciúme, vingança, inveja?

$\mathrm{Na}$ inscrição da tragédia, portanto, uma fatalidade discursiva já se teria indiciado à sua revelia. A semelhança das duas mortes - a da peça de teatro e a de Marta - tornava-se numa espécie de denúncia metafórica de que também a açáo de Lúcio no desenlace ficava implícita, como se ele, afinal, não tivesse feito mais que atender ao chamado do amigo na direção da perdição trágica e fatal que os unia e os comprometia definitivamente: "Vamos ver! Vamos ver!... Chegou a hora de dissipar os fantasmas..."(CL, 122)

Marta era de certo modo a ficção de ambos e a sua existência dependia do mistério e da estranheza que a envolvia: para Lúcio ela funcionava como fulguração passageira que nunca deixara de inspirar nele o trânsito de afeto para Ricardo (lembre-se a cena do beijo como exemplo dessa superposição de imagens); para Ricardo ela funcionava como um duplo de si através de quem ele podia partilhar os afetos no seu próprio corpo feminizado. Recordemos: “...assim éramos nós obscuramente dois, nenhum de nós sabendo bem se o outro não era ele-próprio, se o incerto outro viveria” é a epígrafe da novela de Sá-Carneiro que encontra em Fernando Pessoa a economia da sua proposta: duplo, mistério, morte.

Nesse sentido a epifania destrói o equilíbrio do pacto, desvenda-o através de uma explicação racional, pondo fim à hipótese de plenitude que dissipara temporariamente as divergências e os interditos. O resultado? Esgarça-se o desejo, a morte sobrevém, narcísica na dimensão de Ricardo, fatal e trágica na dimensão de Lúcio. Ambos identificados até o fim, para dissipar seus fantasmas.

A tríade que instituíra Marta como duplo de Ricardo e chama de Lúcio estava desde sempre fadada à morte, único estágio verdadeiramente incorruptível porque ele mesmo definitivo. Seja no desaparecimento de Marta, seja na evidência da morte de Ricardo, seja no mergulho na sensibilidade nostálgica de um Lúcio morto-vivo, o que se revela para os três é, afinal, a mais-que-evidente impossibilidade da plenitude do desejo que os faz mergulhar num vazio literal ou metafórico.

Ricardo tocara através de Marta o limite da obra-prima. E qualquer obra de arte precisa de leitores. Lúcio terá sido um mau leitor porque não soube apreender Marta 
no que ela tinha de dom não exclusivo, não soube perceber que ela tinha sido criada para ser oferecida também a outros leitores, que, como ele, deveriam saber amá-la para que ela pudesse sobreviver - sem exigir dela o dom total, que seria ele próprio uma forma de suicídio porque equivalente ao esquecimento de si. Poderia recuperar aqui uma reflexão de Camus em Le Mythe de Sisyphe:11 "o único amor generoso é aquele que se sabe ao mesmo tempo passageiro e singular". Marta/Ricardo teriam sido um modo de donjuanismo naquilo que entendiam como forma de doar e de fazer viver. Era de uma outra forma de amor que se tratava, um amor liberador, que trazia consigo todos os rostos do mundo, cujo excesso nascia do fato mesmo de se saber perecível e nesse sentido isento de qualquer esperança de eternidade, de qualquer lei moral, de qualquer constrangimento ético. Era esse o seu modo de conhecimento. Interessante pensar que na lógica da linguagem bíblica conhecer corresponde também ao ato de amar.

Lúcio foi um mau leitor. Para ele Marta foi uma "passante" de quem ele teria querido em vão apropriar-se. Sem consegui-lo só lhe restava colaborar com o seu desaparecimento, autor e leitor reunidos enfim no mesmo ato aniquilador. Resta-lhe entâo, morto-vivo que é, a capacidade de formular um último projeto - a escrita da sua confissão que só na superfície seria uma confissáo de inocência, mas antes a de uma falência de entendimento. Nela ele se compraz na rememoraçáo menos para entendê-la do que para revivê-la como discurso, lugar de memória, lugar da sua ficçãa que ele constrói como única e precária permanência possível.

Sá-Carneiro experimentou outrar-se ele próprio em $A$ confissäo de Lúcio. Menos certamente pelas correspondências autobiográficas, demasiado evidentes, que váo do homoerotismo à sedução por Paris, da experiência no meio artístico da capital francesa à insinuação do suicídio, senão, ao fascínio da morte. A sua presença autoral estará antes na aventura daquele desregramento dos sentidos à moda de Rimbaud, em que ele experimenta como um voyant todas as formas de amor, de sofrimento e de loucura, em que esgota dentro de si todos os venenos para guardar deles apenas as quintessências, em que ele se faz doente, criminoso, visionário e maldito para ir ao fundo do desconhecido. Herdeiro de uma atmosfera fin-de-siècle, Mário de Sá-Carneiro é digno representante da modernidade de Orpheu, no que esse grupo de artistas tem de sensibilidade extravagante, de excesso, de iconoclastia, de libertaçáa, de loucura. No avesso da tradição do romance de formação, $A$ Confissão de Lúcio é uma demonstração do gozo não utilitário, do desvio da doxa, numa narrativa que desorienta mais do que ensina.

A frase de Hipócrates - "A vida é curta, a Arte é longa, a ocasião fugidia, a experiência enganadora, o julgamento difícil" - bem poderia funcionar como outra epígrafe de $A$ Confissão de Lúcio. Ela não está lá mas ecoa nos versos de Fernando Pessoa, "A vida é breve, a alma é vasta, ter é tardar", que Lúcio certamente assinaria ao escolher

\footnotetext{
11 "C'est un autre amour qui ébranle Don Juan, et celui-là est libérateur. Il apporte avec lui tous les visages du monde et son frémissement vient de ce qu'il se connait périssable" CAMUS, Albert. Le Mythe de Sisyphe. Paris, Gallimard (Collection Idées), p. 102.
} 
fazer de sua "confissáo" o modo de intuir o único sentimento de eternidade que, para além dos perecíveis afetos, só a alma - e a arte - são capazes de insinuar na nossa precariedade de seres mortais.

Palavras-chave: duplo, narcisismo, voluptuosidade, mise-en-abyme

Resumo: Partindo da proposta de ler $A$ Confissão de Lúcio como um ensaio sobre a voluptuosidade, interessa-me acompanhar o processo de construçáo do duplo a partir do conceito de narcisismo. O conceito freudiano de "estranho" (unheimlich) constituirá a base teórica para a leitura do duplo narcísico, não apenas através do sentido primeiro de não familiar, mas naquilo que ele tem de ambíguo quando entendido como o elemento que deveria ter permanecido oculto, quieto, tranquilo (heimlich) mas que ousou apresentar-se à luz revelando sua estranheza (unheimlich). Daí o medo e o horror que impulsionam à morte. Caberá avaliar as variantes do narcisismo na novela de Sá-Carneiro posto que ele surge de uma autocontemplaçáo voluptuosa, não através de uma miragem no espelho da identificação, mas da possibilidade de produção de um outro ainda mais perfeito de si, nesse caso um desejado outro feminino.

Keywords: double, narcissism, voluptuousness, mise-en-abyme

Abstract: Building on the proposal to read A Confissäo de Lúcio as an essay on voluptuousness, my interest is to go over the construction process of the double in the light of the concept of narcissism. The Freudian notion of "strange" (unheimlich) shall form the theoretical foundation, allowing a read- ing of the narcissistic double not only in the primary sense of unfamiliar, but also in the ambiguity derived from its interpretation as an element that should have remained hidden, silent and tranquil (heimlich), having however dared to present itself in daylight and uncovering its very strangeness (unheimlich); hence the fear and horror leading to death. Variations of narcissism shall be analysed in Sá-Carneiro's novel, given that the narcissistic attitude of the character stems from voluptuous self-contemplation, not as a result of any self-image, but instead deriving from the possibility of producing an Other that is even more perfect than the self - in this case a double he wishes to be a woman.

Mots-clés: double, narcissisme, volupté, mise-en-abyme.

Résumé: Ayant pour but de lire A Confissão de Lúcio comme un essai sur la volupté, il mintéresse d'accompagner le processus de construction du "double" à partir de la notion de "narcissisme". Le concept freudien d' "etrange" (unheimlich) constitue le fondement théorique pour la compréhension du double narcissique, non seulement à partir du sens premier de nonfamilier, mais à un niveau plus ambigu, où le mot peut être conçu comme l'élément qui aurait dû rester occulte, silencieux, tranquille (heimlich) mais qui a pourtant osése présenter en pleine lumière, dévoilant alors son étrangeté (unheimlich). De là la peur et même l'horreur qui mènent à la mort. Il 
faudra étudier les variantes de la notion de narcissisme dans la nouvelle de Sá-Carneiro, une fois quil surgit d'une autocontemplation voluptueuse qui ne se fait plus à partir du miroir de lidentification, mais d'une possibilité outre qui serait capable de produire un autre soi-même encore plus beau ou plus "parfait" dans la mesure où ce serait un désirable autre féminin. 